\title{
Intraethnic Installation of Ukrainian Labour Migrants in the Preservation of Linguistic and Cultural Identity
}

\author{
Irina S. Karabulatova \\ Institute of Socio-Political Research of the Russian Academy of Sciences, Moscow, Russia \\ Email: radogost2000@mail.ru \\ Zinaida V. Polivara \\ Tyumen State University, Tyumen, Russia \\ polivara.z@mail.ru
}

\section{Doi:10.5901/mjss.2015.v6n3s2p142}

\begin{abstract}
The article discusses the specifics of the conservation and transformation of linguistic and socio-cultural norms of the Ukrainian bilinguals living in the Tyumen region, Khanty-Mansi and Yamalo-Nenets Autonomous districts. Today Ukrainians become the object of attention of many members of the scientific knowledge, because there is a real question: how is the differentiation between Russia and Ukraine developed? Tyumen data are presented in comparison with the results of the author's survey of Ukrainians from Poltava and Lvov. Ukrainians take second or third place in number in the Tyumen region, including the district. Migration of peoples on the territory of the North Tyumen, changing of the usual practice, language behavior leads to the extinction of many features of national culture, language, and then to complete his disappearance, but relict features are stored in the form of ethnically motivated intonation and behavioral norms. Our observations show the growing phenomena of mixing of pronunciation norms both in Russian and in Ukrainian speech of Ukrainian bilinguals of North Tyumen, and, also the growing phenomena of socio-cultural conglomeration due to internal ethnic installations. The study of Russian-Ukrainian cooperation in the Tyumen region allows to determine the level of influence of extralinguistic factors on the state of the Ukrainian language and culture in the Diaspora environment.
\end{abstract}

Keywords: Ukrainian bilinguals, ethnic installations, nonethnic environment, diaspora, labour migration.

\section{Introduction}

Reasons, is happening the intensifying of ethnic groups as subjects and objects of ethnopolitical processes, in this regard, there is increasing interest in the study of various Diaspora groups in various aspects, including ethno-linguistic (Akhmetova, B.Z. and othr., 2012; Babenko, V.Y., 1997; Babenko, V.Y., 2007; Bejencev, E.V., Karabulatova, I.S. and Caushe, K.K., 2010; Tyumen region: nations, languages, cultures, 2007; Polivara, Z.V. and Karabulatova I.S., 2011; Polivara, Z.V. and Karabulatova I.S., 2011 (a); Ethnolinguistics of Eurasian continuum, 2009; Ingush diaspora, 2008; Ingush diaspora, 2008; Ingush Diaspora, 2010; Lomakin, O.C. and Shuruhnov, O.A., 2004; Ryazantsev et all, 2014; Shirin, S.S., Bogolubova N.M., and Nikolaeva J.V., 2014; and Thomas et all, 2014). It should be noted that in the development of national and Federative relations gradually is secreted the factor of distinct ethnic group - Diaspora, undergoing a time of revival and exacerbation of national consciousness and national identity, where the factor of language becomes one of the leading (Polivara, Z.V. and Karabulatova I.S., 2011 (a); Karabulatova I.S. and Karelin L.F., 2006; Pticina, N.V., 2007; and Pelaud et all, 2014). Contemporary international migration in the Tyumen region in the intercensal period formed $1 / 3$ of new migrants, of whom $98 \%$ were residents of the CIS and Baltic states. However, the desire to preserve native languages and pass them on to their children is integral feature of almost all Ukrainian migrants (Karabulatova, I.S., 2005). Their children, being in nonethnic language environment, are to simultaneously develop multiple language and cultural systems (Polivara, Z.V. and Karabulatova I.S., 2013; and Polivara Z.V., 2014). Thus linguistic environment where the "carrier" of the two language systems of communication is called bilingual is born.

According to the All-Russian census of population in 2010 in Tyumen region live 157, 3 thousand of Ukrainians. It is the third most populous nation (after Russians and Tatars), inhabiting the territory of the region. The number of Ukrainians decreased compared to 2002, (The Tyumen region: nations, languages, cultures, 2007; and Bogolubova, N.M., Nikolaeva J.V., Fokin V.I., Shirin S.S., Elts E.E., 2013). However, despite a significant number of Ukrainians living 
here, Russian-Ukrainian bilingualism and the state of biculturalism still is not sufficiently investigated. There are a few researches on the functioning of the Ukrainian language outside the metropolis in the post-Soviet space. (Babenko, V.Y., 1997; Babenko, V.Y. 2007; Budjhak, S.V. 1987; Zhluktenko, Y.O., 1964; Zhluktenko, Y.A. 1990; Idze, B., 2002; Karabulatova, I.S., 1997; Karabulatova, I.S., 2001; Karabulatova, I.S., 2004; Karabulatova, I.S., 2006; Karabulatova, I.S., 2007; Karabulatova I.S. and Karelin L.F., 2006; Mlechko, T.P., 2014; Frolov, N.K. and Karabulatova, I.S, 2001; Polivara Z.V., 2008; Polivara Z.V., 2008 (a); Polivara, Z.V. and Karabulatova I.S., 2013). The authors of this article are newcomers in research on language situation, behavior and language consciousness of the Ukrainians of the Tyumen region (Demina, L.V. and Karabulatova, I.S.; Karabulatova I.S., 1997-2007; Karabulatova, I.S. and Karelin L.F., 2006; and Polivara Z.V., 2008).

Ignoring cultural differences between Russians and Ukrainians led to the isolation of Ukrainian labour migrants of post-Soviet era and the growth of Ukrainian public organizations, in which is almost independently develops the life of the Ukrainian community.

\section{Materials and Methods}

The material for this survey was conducted sociological surveys, psycholinguistic and speech therapy examination in conditions of closely related bilingualism, compared with results extracted in the course of the scientific-analytical monitoring of the special literature.

A peculiar set of rules drawn up and written in the Ukrainian language by famous historian, linguist, public figure I. Ogienko is called "the Science of obligations to native language, the catechism in the native language for teachers, writers, clergy, lawyers, students and the general society" (Shirin, S.S., 2015). About the work of I. Ogienko in the Ukrainian scientific field began to write in the years of 2000-2009 (Belaya, E.M., 2000; and Belaya, E.M., 2001). Ukrainian expression «рідномовні обов'зки» used by I. Ogienko, is difficult to translation adequate into a foreign language. After all, we can't say nativelanguage duties? We can say: commitment to native language. The naturalness of this expression in the mouth of Ukrainian speaks for itself, confirming once again the thesis that in this case the language as ethnocentricity factor occupies the first place among others. Let's try to find an adequate expression appropriate to Ukrainian. As the book gives instructions on every Ukrainian family in any circumstances to use the Ukrainian language, to make every effort to preserve its purity and certainly to teach their native language to their children, probably the closest in meaning will be the text: "Responsibilities in respect of the native language". We have paid attention to this issue as in the fact that the book of I. Ogienko there is a separate Chapter on "Obligations to native language in mixed marriages", where we are talking about the strict implementation of Ukrainians certain obligations in relation to the preservation of the native language in mixed marriages. Here are some rules of the "Catechism":

1. Society should strictly follow that its members do not come into mixed marriage.

2. Mixed marriage usually leads to linguistic degeneration, the biggest sin against own nation

3. If your wife is a foreigner (in Ukrainian version of «чужомовна»), literally "belong to foreign language", you must do so that in a family dominate your mother language and that your children study native language since the first year of life. Without this your children are lost to the nation (translation - I. K.).

Today someone can be vexed by a rigid categorical requirements of "Catechism" of I. Ohienko. But you must remember that his book was written at that time (Ohienko, I., 1936), when the Western part of Ukraine was under Polish rule and the Ukrainian language was banned on this territory. Perhaps this rigidity, for so long cultivated in the Ukrainian environment, contributed to the manifestation of distinct national character traits, up to the extreme right-wing sentiments.

Conditions of bilingualism have different impacts on the speech development of the children. Favorable circumstances (absence of pathology, regular lessons of parents with children) contribute to the full absorption of both languages. However, "more often in bilingual environments (especially in cases of priority of one of the languages) there are a lot of speech abnormalities, caused by the interaction of language systems, and speech disorder of non-dominant language, and often both languages" (Karabulatova, I.S. and Polivara Z.V., 2011; Polivara, Z.V. and Karabulatova I.S., 2011(a); Ukraine - Western Siberia: dialogues of cultures and nations, 2007; Karabulatova, I.S. and Polivara Z.V., 2013; and Karabulatova, I.S., 2006).

The researchers argue that " the bilingual thinks on one, or on another language, while those who speak foreign language instinctively translate everything into their native language" (Balkina, N.V. and Makhankova I.P., 2007). On the background of the coexistence of a diversity of languages and dialects, the decrease of the functional role of native languages and, as a consequence, assimilation, and then the disappearance of languages of immigrants is observed. About these consequences of bilingualism in society and in national languages in the linguistic literature it is mentioned at least since 1922, but here it is advisable to pay attention to the latest arguments in the study of bilingualism (Polivara, 
Z.V. and Karabulatova I.S., 2013; Mlechko, T.P., 2014; Russian language personality in modern communicative field, 2012; Language situation in Canada, 2014; and Karabulatova, I.S. and Niyazov G.M., 2007), where we are talking about negative phenomena caused by the so-called collective situation of bilingualism .

Mastering of any language, its norm of pronunciation begins with "sifting through linguistic sieve" the mother language, comparison of the common and opposite. Thus, differential and constitutive characteristics of phonemes, articulatory-acoustic characteristics of sounds are often blurred.

With the aim of studying the transformation of norms of pronubciation of inphones, we studied the phonetic characteristics of pronunciation part of speech in the Ukrainian bilingual children living in the Tyumen region and in Ukraine (Poltava and Lvov regions). Respondents were taken from two groups: 1) the Ukrainians, who live on the territory of the Tyumen region, are not displaced the last time, and are descendants of the migration waves of colonization of the region (Karabulatova, I.S., 2001) and 2) the Ukrainian labour migrants of the post-Soviet time. This gave the opportunity to trace the evolution and transformation of linguistic and cultural attitudes of Ukrainians in isolation from the parent nucleus".

As the Russian language belongs to the East Slavic group of the Indo-European family of languages, the closest languages of this group are Belarusian and Ukrainian. These languages are in constant interaction and mutual influence, which affect on the state of the vocal processes of the native speaker. The main features that distinguish the Russian phonetic system are the lack of short and long vowels and the absence of diphthongs. Rhythm and stress also cause a lot of problems for children bilinguals who learn Russian (Polivara, Z.V. and Karabulatova I.S., 2011; and Polivara, Z.V., 2008). Mainly the rhythmical intonation skills, or rather lack of them, or mismatch with other multi-structural and/or closely related languages, pass them as foreigners (Karabulatova, I.S., 2011; and Akhmetova, B.Z. et all, 2012). In Slavic languages the questions are pronounced with a falling intonation, which is perceived by native speakers as impoliteness, or threat from the communicant.

According to the theory of articulatory approach, developed by the Russian scientists-linguists I. A. Grusinski and K. M. Kolosov, 3 main typological groups of phonemes are highlighted: a) coinciding in both languages; b) divergent C) partially coinciding. The most difficult to master should be recognized the last 2 groups, and with partially coinciding phonemes will be of the biggest difficulty. Indeed, lip sounds $[M],[P],[B]$, in Russian and Ukrainian languages are similar, however, to learn their articulation is much more difficult because of differences in articulation to the untrained ear are not too noticeable. In the Ukrainian language phoneme $[\mathrm{M}]$ has a more pronounced nasality and more low tonality than in English, caused by more pronounced attack when pronouncing the sound and higher concentration focus of sound. This phenomenon is amplified in the case of conversion, requiring changes in the next vowel after [M], [B]: [мамо, бабо].

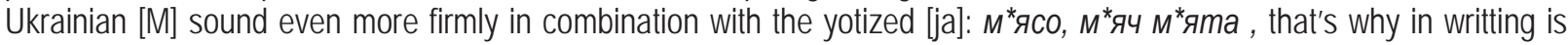
separated from it by a dividing apostrophe. Children bilinguals, trying to adapt their pronunciation under standardized Russian pronunciation, resort to additional consonant [H]: Мнясо, мнята мняч, etc. Labio-dental sounds [V], [F] also have specific features. In the Ukrainian language phoneme [v] is bilabial sonorant fricative sound that is not devocalized in the Russian speech of Ukrainians in the Ukrainian language, [B] turns into non-syllabic [y]. The presence in the Ukrainian language of sustainable combination [хв]: [хвиля, хвіст, хвилястий, вихвалятись, хворий] affects the pronunciation of the sound [F] and raises a number of phonetic errors: [Хведя, хвокус].

With all the seeming cultural proximity between Russians and Ukrainians, we observed the presence of significant cultural distance, expressed in different attitudes towards the family, the mother language, emigration and native land, finance. We examined group of Ukrainian labour migrants of the Tyumen region, including the district, in total 300 people were interviewed.

\section{Results}

A survey of Ukrainian labour migrants identified as extra-linguistic and interlingual differences in linguo-mental the sphere of concepts. Thus, the phonetic feature of Ukrainian bilingual is (as in English) the absence of positional devocalization of sonorous consonants, which manifests itself primarily in the preservation of the voicing of the final: на пля(ж), а(ж) потрогать, до(жд’), как ра(з) снимался, пере(д) тобой, хле(б). Often non-devocolized in absolute end of words and before voiceless consonant remains sound [в]: рако[в], бьчко[в], домико[в], ивето[в]. This is because in Ukrainian [в] is a bilabial-labial sonorant fricative sound that is not devocalized in the Russian speech of Ukrainians (Ukrainian language [B] turns into non-syllabic [y̆]). In a few cases sonority remains before the voiceless at the junction of morphemes: ры[б]ки, коля[Ә]ки, бли[з]ким. Sonorant [P], [Л] have the same articulatory structures, as in Russian, but, according to our observations, among children bilinguals Ukrainians the phenomena of rhotacism are much less common than among Russian children. Probably this may be due to the fact that in the Ukrainian language, the structure of the combination of 
two laminal consonants is sustainable and frequent: [бджоли, дзеркало, джерела, дзьоб, дзвін]. This, in its turn, prepares the articulatory basis for mastering of complex sonora-vibrant. By analogy with the native language, Ukrainian bilinguals often soften the sound $[\mathrm{p}]$ as in the word [бо[рь]m]. The absorption of the phoneme [ת] also has its own specifics. Often it sounds soft: [ласкаво, Ласуня] and has a labial trend of pronunciation. Our study, performed on the territory of Poltava and Lvov regions (2008-2013.), confirmed these assumptions: it was stated that the majority of Ukrainian children, the true native language speakers by 3-4 years of age possess the normalized pronunciation complex of sonoros, requiring the active participation of almost all groups of muscles of the tongue. The greatest difficulties for Ukrainian bilinguals is assimilation of Russian affricates. Ukrainian bilinguals soften the sound [ЦL] by analogy with the native language, as for example, in the word [спе[и'] иально]. However, the hard pronunciation of the consonant sound before sound [и]: [вы]шня unlike Russian soft helps them to grasp the concept of no palatalization of consonants before the vowel [i] as in English language (Canada's Ethnocultural Mosaic, 2006; and Budjhak, S.V., 1987). Ukrainian [sh'] hard before [o] : [щ]] , [щ]] це? And etc. Ukrainian affricate [щ] dj njt decomposed into components: [овощь] (Ukr..) and [овошьть](Rus.), [щастя] (Ukr.) и [счастье] (Rus.), do nor alternates: [дощик](укр.) in compatison with Russian [дождик].

Mismatching of norms of pronunciation causes the phenomenon of attrition (spoilage) in native Ukrainian language. Not only individual sounds, but whole syllables undergo reduction, causing the deformation of the vocal outline of words [сейчас] in the speech of Ukrainian turns into [сичас, щас]. This phenomenon of attrition is the predisposing factor to the emergence of the so-called Surzhik, which should have no place in the literary Ukrainian language.

Ukrainians do often not properly digest the phoneme $[\mathrm{H}]$, because the sound $[\mathrm{h}]$ in the Ukrainian language is always pronounced hard: [ч]уть- чуть, ве[ч]еря, [ч]ерешни, [ч]еремшина, кру[ч]еники, мяч] and in Russian language do not have the hard variant косто[ч]ками, [чеснок]. Ukrainian [ч] is harb before all vowels except [i]: [uinamu]. The phoneme [u] in Russian and Ukrainian languages differ in the place of formation, in the Russian language it is palatolabial, as in the Ukrainian - coronal, alveolar sound. Clarity of pronunciation of this phoneme, in our opinion, can be considered as one of the factors of tachilalia of Ukrainian speech in terms of its "saturation" with sounds [ч], [щ]], causing rapid switching of the organs of speech. In the Ukrainian language - coronal, alveolar sound [4] has articulatory community at the place and method of formation with such sounds-sonorants as [д], [T] and their combinations with coronal whistling [д3] and [дж]. Cacuminal sounds [ш,ж] sound more hard. Although there is no signal indicator as longitude of sound in the Ukrainian language and, but in the flow of sounding speech they are distinguished by bright articulation, oral and acoustic characteristics. If characterizing the general contour of the sounding the Ukrainian language, it can be viewed as somewhat accelerated melodic background with saturation of hushing, affricates and accent of hard vibrant [p] : [nопереджати, перепрошувати, добрый вечір]. Sibilant [c] [3] are shaded and have a different saturation and phonetic load than in Russian. This, in its turn, affects overall grave tonality of the Ukrainian language and reflects the direct interferences of the Polish language.

Certain difficulties at learning of Russian phonetics of Ukrainian children occur with back sounds $[r],[\mathrm{k}],[\mathrm{x}]$. In the Ukrainian language the sound [r] is coronal, fricative consonant. Similar problems arise with the formation of the Russian normalized $[\mathrm{x}]$ and $[\mathrm{k}] . \mathrm{n}$ the Ukrainian language they sound somewhat breathy and always on the soft attack of voice, have no occlusive component: [Катря, куліш, коханий, проханий].

The evolution of the Diaspora takes place in the depths of such general trends as the population increases due to migration groups and activation in the socio-cultural processes because of the expansion of the ethnic factor. Under certain conditions migration may cause complication in inter-ethnic dialogue. Competition and fierce concurrence between cultural-historical types, between "indigenous" and "alien" nations is an obvious tendency in the genesis and evolution of national processes and institutions.

\section{Discussion}

While studing with using the methods of the free choice of self-definition the set of possible identifiactions is becoming even more diverse. One can observe that the choice and preference of certain social categories in order of identification sometimes slightly depends on the degree of its "reality," for example, the USSR is no longer existing, but identification with him is still quite high. This phenomenon calls a "Phantom" of identification (Lebedev N.M, 1997).

Thus, the phonetic system of the Slavic Russian and Ukrainian languages, despite the apparent similarity and commonality, has significant differences. Therefore, difficulties in learning the Russian language by Ukrainian bilinguals are inevitable. It must be clearly understood that the mother (Ukrainian) language will be subjected to interference. Mainly quality mastering of the native language (literary norms) in early childhood is a reliable immunity against attrition, presented by "Surzhik": панчохи-чулки, шкарпетки-носки, сукня-плаття, цукор-сахарь. The balance of languages 
may change in favor of one or another language, if there are appropriate conditions: one of the languages may partially degrade (language attrition), cease to grow (fossilization), be forced out of use (language change), be forgeted, become obsolete (language death); or, conversely, can be reborn (revitalization), maintained (save), be brought to the level of official recognition and use (modernization).

This circumstance will require from specialists an informed psycholinguistic analysis and approach in teaching and learning articulation norms of another language by children bilinguals. Teaching the consonant sounds of the Russian language of Ukrainian bilinguals, it is necessary to pay special attention to articulation, palatalization and aspiration, not always coincident in the language of one of the East Slavic group. It is also needed to realize of how phonemes are connected in words, and then how these words are connected in the sentences, what are the characteristics of structuring sentences of a language. In a natural language environment this is indirectly and simultaneously. The child in a relatively short period of time quite easily attracts pronunciation norm of native language, recognizing speech reality. In terms of a non-native language environment, the formulation of pronunciation skills should devote considerable time and attention. This work does not aim to consider all comparative characteristics of the languages of the contactees, but only raises the existing problems associated with linguistic adaptation of the organs of speech in a foreign language environment.

The complexity and multidimensionality of multilinguism in the context of globalization and migration have led to diverse aspects of the study of bilingualism (linguistic, psycholinguistic, sociolinguistic, cultural, educational) that caused the emergence of numerous scientific works on this problem (Frolov, N.K. and Karabulatova, I.S, 2001; Karabulatova, I.S., 1997; Karabulatova, I.S., 2001; Karabulatova, I.S., 2004; Karabulatova, I.S., 2006; Karabulatova, I.S., 2007; Karabulatova, I.S. and Isakova, A.A., 2007; Polivara, Z.V., 2008; Polivara, Z.V., 2008 (a); Polivara, Z.V. and Karabulatova I.S., 2011(a); Polivara, Z.V. and Karabulatova I.S., 2013; Zamaletdinov et all, 2014; Chilvers S. and Walton-Roberts, 2008; Malik, Sh. and Singh A., 2014). In this connection, Dr.Shipra Malik and Dr. Anupriya Singh fairly raise the question of the preservation of identity in the context of globalization and changes in the socio-cultural behavior as well as nationsparticipants of migration and its individual representatives in the course of globalization processes on the example of the people of India, whose are members actively integrating into the American reality. (Malik, Sh. and Singh A., 2014). It is generally accepted that migrant workers do not have any influence on linguistic and socio-cultural life of the host society. However, this superficial view turns to be untenable under detailed consideration of the problem. The problem is that on the background of the coexistence of a diversity of languages and dialects, the decrease of the functional role of native languages and, as a consequence, assimilation, and then the disappearance of languages of immigrants are observed. (Polivara, Z.V. and Karabulatova I.S., 2011 (a)), who at first also acted as labour migrants on the territory of the Tyumen region (Karabulatova, I.S., 2011).

Thus, linguistic-cultural setups of Ukrainian labor migrants in their implementation is a multidimensional phenomenon requiring a synthesized approach to its study.

\section{Conclusion}

Long, for centuries, life in the Diaspora as an foreigner, low status and vulnerable minorities, specific economic specialization has gradually formed a special type of person, his lifestyle, the model of economic behavior, value system. Communication in the religious practice of the Ukrainian Diaspora of the Tyumen region is realized in Russian and Ukrainian languages. In domestic rituals of Tyumen Ukrainians "national" Christianity and the relics of paganism remain.

Communication in regional social-political practice is presented by national oriented Newspapers («Кущ калини», "Voice of Ukraine in Western Siberia"), staged events (holidays, evenings of national culture, concerts, conferences and etc.), television and radio broadcasts in their native language. The language here serves as a way for the manifestation of own ethnicity and the nature of the individual's ethnic identity. Ambiguous is communication in the domestic sphere of the Ukrainian Diaspora of the Tyumen region. The level of knowledge of the Ukrainian language by other ethnic members of mixed families and their children may be different depending on extralinguistic factors. Sociolinguistic facts shows: Ukrainians speaking the language of their ethnic group, make up a small percentage (steadily decreasing every year). The younger generation of Ukrainian ethnos in the Tyumen region, as a rule, is not fluent in written form of the Ukrainian literary language, in his speech practice makes greater use of the Russian language. Ukrainian language, operating only in the domestic sphere, is subject of strong assimilation. In addition, as the Ukrainian languageis mastered by children spontaneously and they own it unconsciously, that is, not being aware of certain linguistic phenomena, the Ukrainian language has interfering effect on their Russian speech.

The fact of migration, meaning "leap into the uncertanity", the gap between the right existence, centuriesestablished structure and rhythm of life dramatically increased the value of such human qualities as flexibility, dynamism, 
initiative, ability to navigate in a completely new and rapidly changing circumstances. Linguistic and cultural system in a polyethnic environment form the various linguistic and cultural situations, which are a dynamic and wave interaction process languages and cultures in the historical cultural regions and social spheres.

\section{References}

Akhmetova, B.Z., Zhumagulova N.S., Karabulatova I.S., Caushe K.K., and Polivara Z.V., 2012. Linguistic personality in transforming the community. Collective monograph. Tyumen: Vector Buk, $192 \mathrm{pp}$.

Babenko, V.Y., 1992. Ukrainians in the Bashkir SSR: the Behavior of a small ethnic group in the poly-ethnic environment. Ufa: BSC, Ural branch of the Russian Academy of Sciences, $260 \mathrm{pp}$.

Babenko, V.Y. and Babenko S.V., 2007. Ukrainians of Bashkortostan: the main trends of ethnic and cultural development. In the: Third Balakovski reading. The culture of the Orenburg region: history and modernity: scientific-educational and cultural almanac. Orenburg: Printing house "Dimur", 118-129 pp.

Balkina, N.V. and Makhankova I.P., 2007. The translation step by step: a guide to the translation. M., Publishing house The university of friendship. 25-35 pp.

Bejencev, E.V., Karabulatova I.S. and Caushe K.K., 2010. Tyumen region - Kazakhstan: the specificity of the state ethno-linguistic policy. Tyumen: Vector-Buk. 124 pp.

Belaya, E.M., 2000. Conceptual charter of native language responsibilities I. Ogienko.In: Scientific Bulletin of the South Ukrainian state pedagogical University. K.D. Ushinsky. Collection of scientific works. Vol. 7 - 8, Odessa. 70-76 pp.

Belaya, E.M., 2001. The concept of language education. Ogienko. In: Science and education, \# 2 - 3. 100-103 pp.

Budjhak, S.V., 1987. Lexical interference in the English-Ukrainian bilingual Canada. M: INION. 48 pp.

Demina, L.V. and Karabulatova, I.S., 2004. Features of ethnomusicological code of lullabies of Ukrainians in Tyumen region. In: Ukraine - Western Siberia: the dialogue between peoples and cultures. Tyumen. 35 - 39 pp.

Zhluktenko, Y.O., 1964. Ukrainska-englisch mimoun vancini. Ukrainian language in the USA, Canada. Kiev: Kiev University. 167 pp.

Zhluktenko, Y.A., 1990. Ukrainian language on the linguistic map of Canada. Kiev: Nauk. Dumra, 176 pp.

Idze, B., 2002. Ukrainian Diaspora in Russia, M. 246 pp.

Ingush Diaspora in Tyumen region: socio-cultural and ethno-linguistic problems of preservation of identity in the foreign environment, 2008. Edited Sampiev I.M., Karabulatova I.S. Nazran: Pilgrim, 274 pp.

Ingush Diaspora in the Tyumen region: problems of preservation of language and culture, 2010. Collect. The monograph. Tyumen: Ed.the Tyumen state University, $328 \mathrm{pp}$.

Karabulatova, I.S., 1997. The interaction of Russian and Ukrainian languages in the Russian Priishime toponymy. In: Ecology of culture and education: Philology, philosophy, history. Tyumen. 34-38 pp.

Karabulatova, I.S., 1997 (a). Ukrainian gidronimicheskaya plan in toponymy Russian Priishime. In: Principles and methods of functionalsemantic description language: results, trends and prospects. Conference materials. Simferopol. 9-12 September 1997. Simferopol, 121-122 pp.

Karabulatova, I.S., 2001. Regional ethnolinguistics: Modern ethno-linguistic situation in the Tyumen region. Tyumen. 226 pp.

Karabulatova, I.S., 2005. The culture of childhood in Tyumen region: tradition and modernity. Tyumen: Academy

Karabulatova, I.S., 2004. To the problem of ethnic identity of Ukrainians in Western Siberia. In: Ukraine - Western Siberia: the dialogue between peoples and cultures. Tumen. $31-34 \mathrm{pp}$.

Karabulatova, I.S., 2006. Specify of Ukrainian folklore in Tyumen region: to the question of functioning in foreign district (ethnopsycholinguistics aspect). In the: Ukrainskoe izmirenie Mineralni collection), international collection of informational, educational, scientific, methodological articles from Ukraine and the Diaspora - Nizhyn-Kiev: NIU them.M. Gogol. 8-9 pp.

Karabulatova, I.S. and Karelin L.F., 2006. The Ukrainian Diaspora of the Tyumen region: history, language, culture. Tyumen, Pub. "Pechatnik". 180 pp.

Karabulatova, I.S., 2007. To the problem of the Ukrainian toponims outside Ukraine: new Ukrainian plast in the onomastic subsphere. In: Ukraine - Western Siberia: the dialogue of cultures and peoples. The Ukrainian Diaspora in poly-ethnic region: Materials of international scientific-practical conference. , Tyumen, November 10, 2007. Tyumen: Printing "Pechatnik". 26-30 pp.

Karabulatova, I.S. and Isakova A.A., 2007. The specificity of functioning of the Ukrainian Rahmaninov in the language space of modern Russia. In: Ukraine - Western Siberia: the dialogue of cultures and peoples. The Ukrainian Diaspora in poly-ethnic region: Materials of international scientific-practical conference. , Tyumen, November 10, 2007. Tyumen: Typography «Pechatnik». 73$77 \mathrm{pp}$.

Karabulatova, I.S. and Niyazov G.M., 2007. Ukrainian national traditions in modern ethnolinguistischen space multi-ethnic region: the problem archegonia and anarchopedia. I: Ukraine - Western Siberia: the dialogue of cultures and peoples. The Ukrainian Diaspora in poly-ethnic region: Materials of international scientific-practical conference. , Tyumen, November 10, 2007. Tyumen: Typography «Pechatnik». 77-83 pp.

Karabulatova, I.S., 2007 (a). Ukrainian language in onomasticon subrostrata other States. In: II international Congress of UKRAINIAN EDUCATION IN the WORLD of time and space". Kiev: Scientific-research Institute of Ukrainian national Academy of Sciences of Ukraine. 345-351 pp.

Karabulatova, I.S., 2009. The image of Ukraine in the modern Russian language consciousness: onomastic myth space. In: Materials of International scientific-practical "Ukrainian studies in Russia: history, status and trends". M. 28-36 pp. 
Karabulatova, I.S., 2011. Linguistic personality in the space of intercultural communication. In: Vestnik KSUCA, Kemerovo, \#17. 33- 40 pp.

Lebedev N.M, 1997. Syndrome of foreign ethnicity and the ways of its Preodolenie. In the Ethnic psychology and society. M. Old orchard. 104-114 pp.

Lomakin, O.C. and Shuruhnov, O.A., 2004. To the question about multi-linguistic culture. In: Educational aspects of tourism: management, marketing, innovation, communication: the Collection of materials and reports interregional scientific-practical conference with international participation. Tula. 206-208 pp.

Malik, Sh. and Singh A., 2014. Abstruseness of Identities and Belongingness in Jhumpa Lahiri' S Namesake. In: International Journal of Research (IJR), Vol.1, Issue 8. 349-355 pp.

Mlechko, T.P., 2014. Russian language personality in multicultural environment abroad. Abstract of Dr. of Phil. Sc. M. PFUR. 38 pp.

Ohienko, I., 1936. The science of obligations to native language. The catechism in their native language for teachers, employees of the pen, clergy, lawyers, students and the General public. Kiev. 456 pp.

Polivara, Z.V., 2008. The problem phonetic dysfunction Ukrainian bilingual children living in the Tyumen region. In: Materials of international scientific-practical conference "Ukraine - Western Siberia in the dialogue of cultures and peoples: vectors and factors of interaction". Tyumen: Pechatnik. 23-27 pp.

Polivara, Z.V. and Karabulatova I.S., 2011. To the problem of speech dysfunction in children bilingual in multi-ethnic space. In: the Cultural life of the South of Russia. Krasnodar: Krasnodar state University of culture and arts. So 5, \#43. 64-67 pp.

Polivara, Z.V. and Karabulatova, I.S., 2011 (a). Linguistic personality in the transforming community: ethnolinguistic differentiation Tatars bilingual in alien surroundings. Tyumen: Pechatnik. $146 \mathrm{pp}$.

Polivara Z.V., Karabulatova, I.S., 2013. Linguistic personality in the transforming community: ethnolinguistic differentiation Tatars bilingual in ethnically different environment. M.: Publishing house "Science", "FLINT", 2nd edition, stereotyped edition. 132 pp.

Pticina, N.V., 2007. To the question about the formation of a secondary language personality (on the material of learning Japanese language and culture). In: Modern problems of science and education, \#3. 59-63 pp.

Russian language personality in modern communicative space, 2012. Materials of the International scientific conference. resp. editor $\mathrm{E}$. C. Belogortseva. - Biisk: "FSBEI HFE ASAE", 160 pp.

Ukraine - Western Siberia in the dialogue of cultures and peoples, 2007. The Ukrainian Diaspora in poly-ethnic region.In: Materials of international scientific-practical conference, Tyumen. Ed. by I.S. Karabulatova. Pechatnik. 204 pp.

Ukraine and Western Siberia: a dialogue of cultures and peoples, 2008. Vectors and interaction factors.In: Materials of international scientific-practical conference. Ed. by I.S. Karabulatova. Tyumen: Pechatnik. 149 pp.

Frolov, N.K. and Karabulatova, I.S, 2001. Ukrainian component in socio-linguistic and onomastic space Tyumen Phobia. In: Scientific notes. Series: Philological science. Kirovograd, Publ.37. 75-79 pp.

The language situation in Canada: contemporary aspects of the Anglo-Ukrainian bilingualism [electronic resource], 2014. http://bo0k.net/index.php?p=achapter\&bid=7900\&chapter=1.

Shirin, S.S., 2015. Corruption in higher education in Russia - First decade of the 21st century International Education Studies, 8 (2), 160 $168 \mathrm{pp}$.

Shirin, S.S., Bogolubova N.M., and Nikolaeva J.V., 2014. Application of David Easton's model of political system to the world wide web Sergey Sergeevich Shirin. World Applied Sciences Journal, 30 (8), 1083-1087 pp.

Bogolubova, N.M., Nikolaeva J.V., Fokin V.I., Shirin S.S., Elts E.E., 2013. Contemporary problems of cultural cooperation: Issues in theory and practice. Middle East Journal of Scientific Research, 16 (12), 1731-1734 pp.

Canada's Ethnocultural Mosaic, 2006 Census. http://www12.statcan.ca/english/census06/analysis/ethnicorigin/pdf/97-562-XIE 2006001. pdf.

Chilvers S. and Margaret Walton-Roberts, 2008. Introduction: Deconstructing the (Re)construction of the South Asian Identities in Canada. In: Diaspora: A Journal of Transnational Studies. Volume 17, \#2, 121-129 pp.

Karabulatova, I.S. and Polivara Z.V., 2013. Turkic and Slavs: bi-polylinguism in globalization and migrations (on an example of Tumen region)Turkic and Slavs: bi-polylinguism in globalization and migrations (on an example of Tumen region). In: Middle-East Journal of Scientific Research 17 (6): 832-836 pp.

Pelaud, I.T., Lan Duong, M.B.Lamm, and Kathy L.Nguyen, 2014. An Anthology of Art and Literature by Southeast Asian Women in the Diaspora. Troubling borders, University of Washington Press, Asian American Studies, Gender Studies, Literary Studies, American Art. 284 pp.

Zamaletdinov, R.R., Karabulatova I.S., Yarmakeev I.E. and Ermakova E.N., 2014. Linguo-Propaedeutics of Ethnic Conflicts as a Basis for Stability in Complex Polyethnic Regions. In: Asian Social Science. Vol 10, No.20. 